\title{
ESTUARINE MESOZOOPLANKTON DYNAMICS ON A SHORT-TERM TIME SCALE: ROLE OF SEMIDIURNAL TIDAL CYCLE
}

\author{
María Clara Menéndez ${ }^{1}$, María Cintia Piccolo ${ }^{1}$, Mónica Susana Hoffmeyer ${ }^{I}$ and Maximiliano Sassi ${ }^{2}$ \\ ${ }^{1}$ Instituto Argentino de Oceanografía \\ Consejo Nacional de Investigaciones Científicas y Técnicas \\ (Camino La Carrindanga km 7.5, B8000 FWB Bahía Blanca, Argentina) \\ ${ }^{2}$ Wageningen University \\ Hydrology and Quantitative Water Management, Environmental Sciences Group \\ (Atlas, Droevendaalsesteeg 4, 6708 PB, Wageningen, The Netherlands)
}

Descriptors: Mesozooplankton, Acartia tonsa, Tidal variability, Estuaries, Argentina.

Descritores: Mesozooplancton, Acartia tonsa, Ciclo de marea, Estuário, Argentina.

In estuaries and coastal areas, planktonic organisms are subject to tidal, diurnal and seasonal environmental changes (MARQUES et al., 2009). Knowledge of the variability of zooplankton communities on different spatial and temporal scales is a prerequisite for the understanding of ecosystem dynamics. Tidal currents and estuarine circulation are well known phenomena that contribute to both vertical and horizontal redistribution of planktonic organisms (MORGADO et al., 2003. Moreover, biological mechanisms may also account for a significant part of the temporal variation in zooplankton community structure (MARQUES et al., 2009). Planktonic communities have presumably developed adaptations in order to compensate for or resist dispersive losses (LAM-HOAI et al., 2006), thus resulting in recurrent patterns of zooplankton distribution. The Bahía Blanca Estuary constitutes a mesotidal system with a semidiurnal tidal cycle, the tides being one of the most important sources of energy (PERILLO; PICCOLO, 1991). The temporal and spatial dynamics of the mesozooplankton in this estuary have been extensively investigated (e.g. HOFFMEYER 2004; HOFFMEYER et al., 2008) but none of these studies has considered the short-term variability associated with tidal cycles. The objectives of the present study were to describe the influence of the tidal cycle on mesozooplankton variability and to compare the mesozooplankton distribution of two zones in the main channel of the estuary: its northern margin and the deeper central zone.

The Bahía Blanca Estuary is a coastal plain system $\left(38^{\circ} 45^{\prime} \mathrm{S} ; 62^{\circ} 22^{\prime} \mathrm{W}\right)$ on the Atlantic coast of Argentina (Fig. 1). It is formed by several NW to SE tidal channels separated by extensive intertidal flats, low marshes and islands (PICCOLO; PERILLO, 1990). The tides and winds have been considered the main factors controlling the water turbulence processes (PICCOLO; PERILLO, 1990), especially in the inner zone where the tidal height is maximal (tidal range of up to $3.6 \mathrm{~m}$ ). Tidal currents are reversible with maximum surface velocities of about $1.3 \mathrm{~m} \mathrm{~s}^{-1}$ and maximum vertically averaged values of 1.2 and $1.05 \mathrm{~m} \mathrm{~s}^{-1}$ for ebb and flood conditions, respectively (CUADRADO et al., 2005). The inner zone of the estuary is relatively shallow (4-7 $\mathrm{m}$ at the channel margin and a mean depth of $10 \mathrm{~m}$ in the central zone of the channel), well mixed and highly turbid as a result of the combined effect of winds, tidal currents and river discharge. Sampling was carried out on 12th May 2006, during a transition from spring to neap tides (Fig. 1). Samples were taken over a 14-h period at two stations (S1, S2) located in the inner zone of the estuary (Fig. 1). S1, Puerto Cuatreros, coincides with the northern margin of the principal channel and S2 is located in the central zone of the main channel, approximately $200 \mathrm{~m}$ away from S1 (Fig. 1). Zooplankton samples were collected during the daytime every $3 \mathrm{~h}$ (from a boat in S2), beginning at high tide. Two submersible pumps were used to obtain simultaneous surface and bottom samples and a PVC hose linked the pumps to $200 \mu \mathrm{m}$ pore size plankton nets. Water was filtered through the nets for 10-20 min, for a total sample volume between 1.5 and 2.9 $\mathrm{m}^{3}$. The collected material was preserved in a buffered solution of $4 \%$ formaldehyde. To estimate the water volume sampled, the flow rate of the pumps was calculated before and after each sampling time by recording the time taken to fill a known volume of water. Vertical profiles of temperature and salinity were obtained with a digital multisensor Horiba U-10 and additional surface and bottom water samples (through pumping water) were taken to determine suspended particulate matter (SPM). Measurements of current velocity were made using a $1.5 \mathrm{MHz}$ Acoustic Doppler Profiler (ADP) located near S2. The tidal height was continuously measured by means of a tidal gauge and all data concerning winds were obtained via a meteorological base installed on the pier. Zooplankton samples were sub-sampled (1/10) and all 
individual taxa were counted. The abundance of taxa was expressed as the number of individuals per cubic meter (ind. $\mathrm{m}^{-3}$ ). The SPM was determined filtering $250 \mathrm{ml}$ of water through previously dried and weighed Whatman GF/C filters $(0.45 \mu \mathrm{m})$. Filters were then dried at $60^{\circ} \mathrm{C}$ for $24 \mathrm{~h}$ and weighed for SPM estimation.

In this study, the wind effect was almost negligible throughout the sampling period: with mean wind velocities of $6.7 \mathrm{~km} \mathrm{~h}^{-1}$ in the morning (mainly from the NNE) and $14.9 \mathrm{~km} \mathrm{~h}^{-1}$ in the afternoon (mainly from the NW). Therefore, the short-term variability observed in the measured variables was mainly due to the semidiurnal tidal influence. Tidal height varied between 1.18 and $5.1 \mathrm{~m}$, low water slack occurred at 13:00 $\mathrm{h}$ and high water slack at 6:30 and 19:00 h (local time). Instantaneous tidal currents ranged from $<0.2$ to $0.8 \mathrm{~m} \mathrm{~s}^{-1}$ according to the semidiurnal tidal cycle (Fig. 2). Maximum velocities were observed during the ebb, $\sim 3 \mathrm{~h}$ after high tide, while minimum velocities $\left(<0.2 \mathrm{~m} \mathrm{~s}^{-1}\right)$ corresponding to slack water occurred at high and low tide (Fig. 2). Tidal flows were asymmetrical so the ebb currents had a shorter duration, but were stronger than at the flood $\left(\sim 0.5 \mathrm{~m} \mathrm{~s}^{-1}\right)$. In both ebb and flood phases, velocities were higher near the surface (Fig. 2). Temperature values seemed to follow the course of the tide, with maximum temperatures around high tide (12.5$12.8^{\circ} \mathrm{C}$ ) and minimum during the ebb or low tide
(11.6-12. $\left.1^{\circ} \mathrm{C}\right)$. Water salinity $(33.8-36)$ co-varied with tidal height, showing the lowest salinity at low tide, according to the expected result of the advection of the lateral salinity gradients typical of an estuary with major freshwater input at the head (GUINDER et al., 2009). The water column was always vertically mixed as indicated by temperature (mean gradient: 0.015 and $0.011{ }^{\circ} \mathrm{C} \mathrm{m}^{-1}$ for $\mathrm{S} 1$ and $\mathrm{S} 2$, respectively) and salinity vertical profiles $(0.035$ and 0.043$)$. SPM varied between 26.8 and $94.8 \mathrm{mg} \mathrm{L}^{-1}$ and showed similar temporal patterns at the surface and at the bottom of the water column (Fig. 3). The highest SPM concentration was around ebb tide at both sampling stations although in S2, high concentrations were also detected during flood tide (Fig. 3). Considering that bottom sediment resuspension is controlled by the near-bed shear stress (which is a function of current speed) (VELEGRAKIS et al., 1997), the maximum SPM concentrations observed in association with the energetic ebb currents indicate that bottom sediment resuspension is likely to account for the observed changes in SPM concentration. Other researches related to SPM tidal variability in estuaries have reported different patterns associated not only with resuspension but also with advective processes and river discharges (CLOERN et al., 1989; WEEKS et al., 1993; VAN DE KREEKE et al., 1997; VELEGRAKIS et al., 1997).

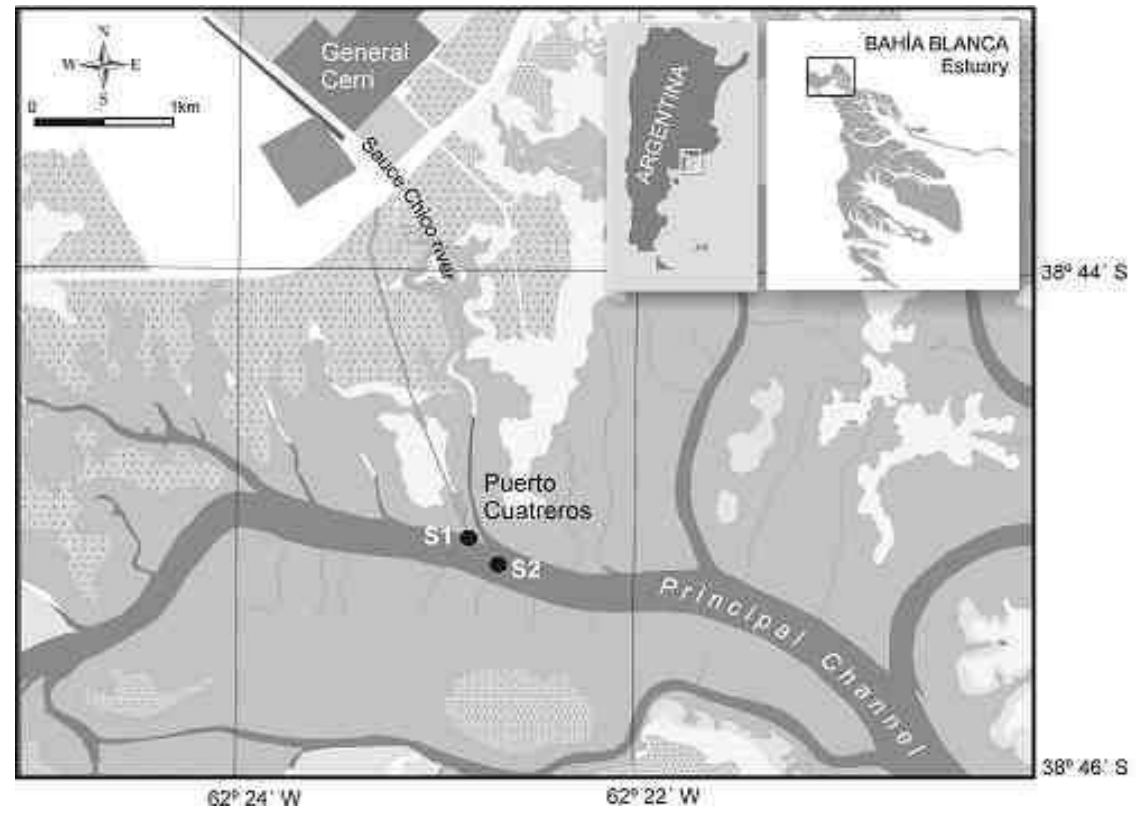

Fig. 1. Inner zone of the Bahía Blanca Estuary and location of the two sampling stations (S1, S2). S1: Puerto Cuatreros, northern margin of the main channel. S2: central main channel, $200 \mathrm{~m}$ away from $\mathrm{S} 1$. 
After analyzing all the samples, a total of 23 taxa were identified in this survey, 17 of which were observed at both sampling sites. The holoplankton fraction represented $39.1 \%$ of the total taxa observed whereas the remaining percentage corresponded to meroplankton $(34.8 \%)$ and adventitious organisms (26.1\%). Copepods occurred at all tidal phases and were the dominant group at both stations. The calanoid copepod Acartia tonsa dominated the mesozooplankton community numerically, accounting for more than $95 \%$ of the total zooplankton abundance. Lower densities of Paracalanus parvus, benthic harpacticoids, estuarine larvae of polychaetes and the amphipod Corophium sp. were also found at both sites. Some individuals of Labidocera fluviatilis and the cladoceran Bosmina longirostris were only registered at S2 and their contribution to the total mesozooplankton was very small. On the other hand, bivalve larvae, foraminifera and the amphipod Caprella sp. were only present in the margin area.

A. tonsa abundances registered at the channel margin (S1) were in general higher near the surface throughout the tidal cycle and fluctuated between 11.34 and 2941.34 ind. $\mathrm{m}^{-3}$ at the surface and between 56.77 and 661.88 ind. $\mathrm{m}^{-3}$ at the bottom (Fig. 4). The abundance of this species was markedly higher during ebb tide (2853.6 ind. $\mathrm{m}^{-3}$ ) than during flood, low or high tide events (Fig. 4). A. tonsa abundances in the central main channel (S2) ranged from 222.81 to 987.50 ind. $\mathrm{m}^{-3}$ at the surface and from 298.78 to 1533.01 ind. $\mathrm{m}^{-3}$ at the bottom (Fig. 4). Contrary to what occurs in the margin area, the abundances in the central main channel were higher near the bottom during the entire tidal cycle and no marked increase of the abundance was detected during ebb tide (Fig. 4). These results showed a daytime scenario in which the short-term temporal variability of the dominant species A. tonsa was strongly affected by tidal dynamics. The interdependence of planktonic organisms' exchanges with water circulation in order to control the seaward transport arises mainly from differences in the density between flood and ebb tides (MORGADO et al., 2003). Thus, the distributional pattern observed for $A$. tonsa could be related to a retention mechanism of this species in the inner zone of the Bahía Blanca Estuary. The increase of the abundance during ebb tide only at S1 may be associated with a lateral movement of this species to areas of decreased flushing such as the channel margins. This option has been suggested for different copepod species in order to enable them to resist the seaward net flow during the ebb (CRONIN et al., 1962; RODDIE et al., 1984; CASTEL; VEIGA, 1990), but until now there are few data illustrating this. In this study, we have always registered the highest abundances of A. tonsa in a zone of net residual landward flow. This may be interpreted as a mechanism that prevents individuals from being washed out of the estuary considering that landward residual currents help to maintain the populations in the estuaries (CASTEL; VEIGA, 1990). In the central channel, the greater proportion of the population near the bottom would reduce the advective losses considering that the residual flow is landward near the bottom (PERILLO; PICCOLO, 1991). Additionally, the net transport is completely landward in the shallower parts such as the margins (PERILLO; PICCOLO, 1991).

Mechanisms by which estuarine mesozooplankton enhance retention in particular regions have been subjected to different interpretations including behavioral responses as well as purely hydrological mechanisms. CASTEL and VEIGA (1990) suggested that Eurytemora affinis populations in the Gironde Estuary, France, are maintained through the same hydrological processes that trap and concentrate suspended particles. Similar results were mentioned by MORGAN et al. (1997) for Coullana canadensis in the Columbia River Estuary, USA, where the abundance distribution mirrors that of SPM. Hough and Naylor (1991, 1992), however, observed tide-related vertical migrations of $E$. affinis in the midestuary region of the Conway River Estuary in Wales. In our study, patterns of abundance and distribution of A. tonsa did not match those of SPM, suggesting that additional mechanisms beyond hydrodynamic processes would maintain the populations in the inner zone of the Bahía Blanca Estuary. The high abundances of this species observed during ebb tide at the margin and near the bottom in the central channel, where there are landward residual currents, provide evidence about the existence of some mechanism that allows the species to avoid stronger surface currents during the receding tide. Determination of whether such a retention mechanism operates for A. tonsa in the Bahía Blanca Estuary awaits further studies not only considering other sampling stations but also complementary observation of the behavior of individual copepod species.

This study represents a contribution to the knowledge of the mesozooplankton dynamics over tidal time scales. The results highlight the role of tides as forcing agents on the mesozooplankton community structure and emphasize the importance of the biological-physical interactions on a short-term time scale in coastal systems. In addition, and although this study is restricted to samples collected during a short period of time, the results show how variable the mesozooplankton community structure can be over short time scales in mesotidal temperate estuaries. This variability should be taken into account for any mesozooplankton monitoring program conducted in a temperate system with a high-tidal regime. 


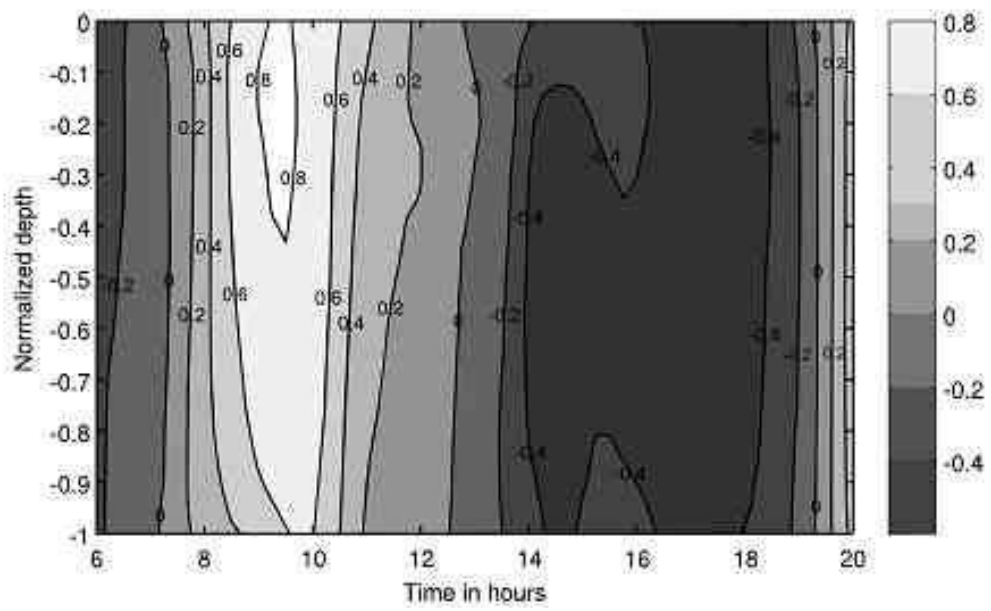

Fig. 2. Longitudinal component of the velocity $\left(\mathrm{m} \mathrm{s}^{-1}\right)$ in the central point of the main channel (S2) as a function of normalized depth for a complete tidal cycle. Positive values of water velocity represent the ebb tide and negative the flood tide.

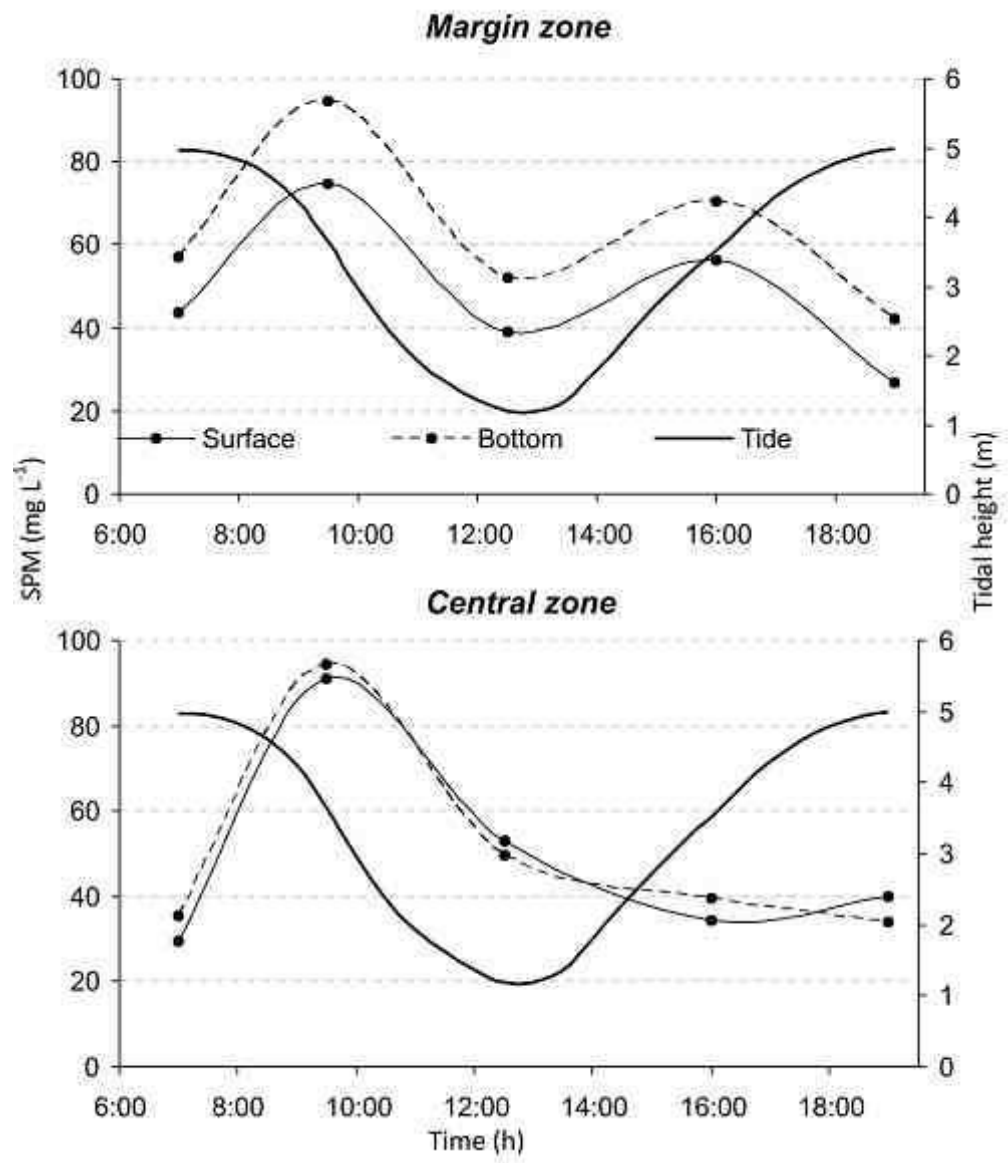

Fig. 3. Temporal distribution of SPM in the two sampling stations of the main channel. 


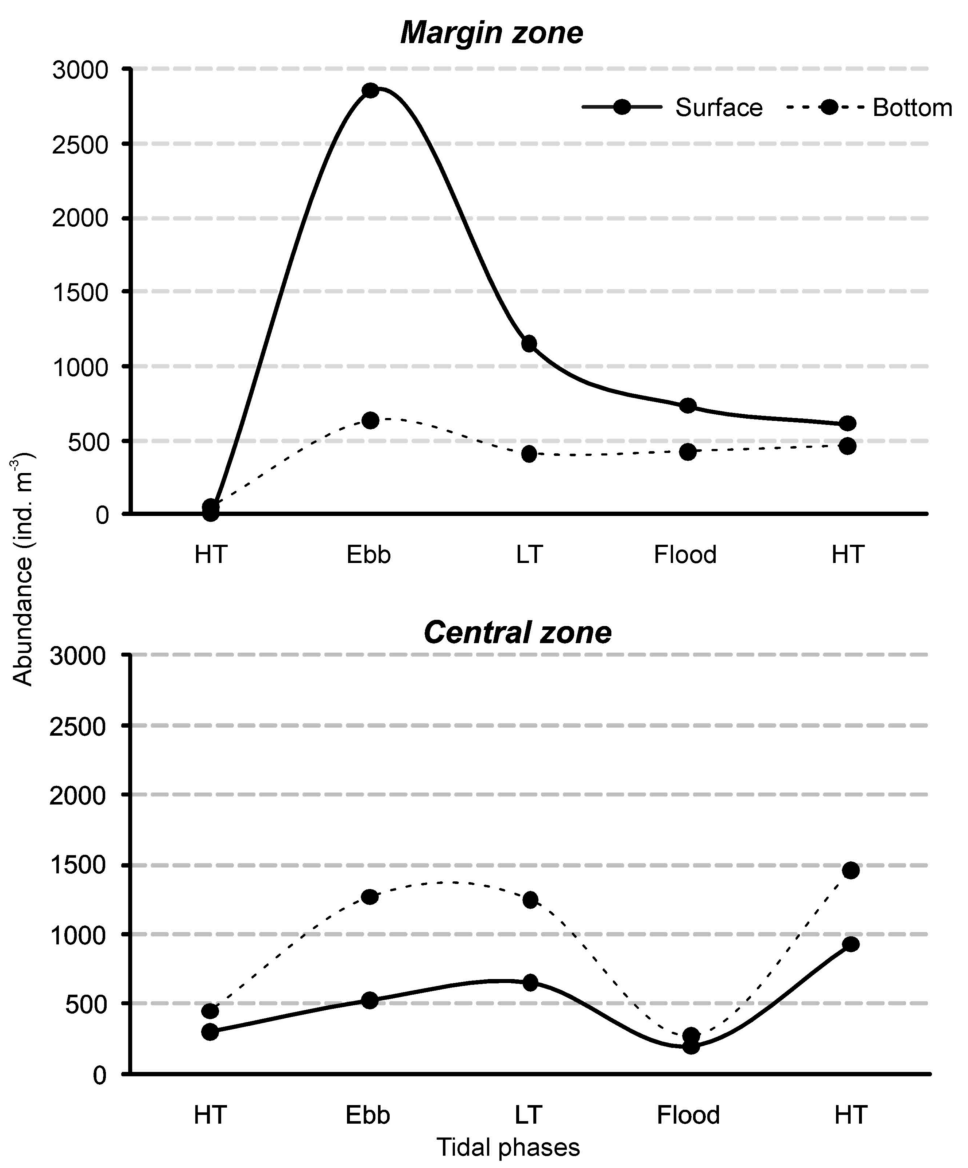

Fig. 4. Abundance distribution of A. tonsa in the two sampling stations of the main channel. HT: high tide, LT: low tide.

\section{ACKNOWLEDGEMENTS}

We wish to thank Luis Kaufman for his participation in the field work and Biol. M. Sofía Dutto and Luciano C. Salotto for their revision of the manuscript. We also thank Walter Melo for drawing the map of the estuary. The authors wish to express their gratitude to the anonymous reviewer for his helpful suggestions on the early version of the manuscript.

\section{REFERENCES}

CASTEL, J.; VEIGA, J. Distribution and retention of the copepod Eurytemora affinis hirundoides in a turbid estuary. Mar. Biol., v. 107, n. 1, p. 119-128, 1990.

CLOERN, J. E.; POWELL, T. M.; HUZZEY, L. M. Spatial and temporal variability in South San Francisco Bay
(USA). II. Temporal changes in salinity, suspended sediments, and phytoplankton biomass and productivity over tidal time scales. Estuar. coast. Shelf Sci., v. 28, p. 599-613, 1989.

CRONIN, L. E.; DAIBER, J. C.; HULBERT, M. Quantitative seasonal aspects of zooplankton in the Delaware River Estuary. Chesapeake Sci., v. 3, n. 2, p. 63-93, 1962.

CUADRADO, D. G.; GÓMEZ, E. A.; GINSBERG, S. S. Tidal and longshore sediment transport associated to a coastal structure. Estuar. coast. Shelf Sci., v. 62, p. 291300, 2005.

GUINDER, V. A.; POPOVICH, C. A.; PERILLO, G. M. E. Short-term variability in the phytoplankton and physicochemical variables in a high-tidal regime, Bahia Blanca Estuary, Argentina. Braz. J. Oceanogr., v. 57, n. 3, 2009.

HOFFMEYER, M. S. Decadal change in zooplankton seasonal succession in the Bahía Blanca estuary, Argentina, following introduction of two zooplankton species. J. Plankt. Res., v. 26, n. 2, p. 181-189, 2004. 
HOFFMEYER, M. S.; BERASATEGUI, A. A.; BEIGT, D. PICCOLO, M. C. Environmental regulation of the estuarine copepods Acartia tonsa and Eurytemora americana during coexistence period. J. mar. biol. Ass. U.K, v. 89, p. 355-361, 2008.

HOUGH, A. R.; NAYLOR, E. Field studies on retention of the planktonic copepod Eurytemora affinis in a mixed estuary. Mar. Ecol. Prog. Ser., v. 76, p. 115-122, 1991.

HOUGH, A. R.; NAYLOR, E. Endogenous rhythms of circatidal swimming activity in the estuarine copepod Eurytemora affinis (Popped). J. expl mar. Biol. Ecol., v. 161, p. 27-32, 1992.

LAM-HOAI, T.; GUIRAL, D.; ROUGIER, C. Seasonal change of community structure and size spectra of zooplankton in the Kaw River estuary (French Guiana). Estuar. coast. Shelf Sci., v. 68, p. 47-61, 2006.

MARQUES, S. M.; AZEITEIRO, U. M.; MARTINHO, F.; VIEGAS, I.; PARDAL, M. A. Evaluation of estuarine mesozooplankton dynamics at a fine temporal scale: the role of seasonal, lunar and diel cycles. J. Plankt. Res., v. 31, n. 10, p. 1249-1263, 2009.

MORGADO, F.; QUEIROGA, H.; MELO, F.; SORBE, J.- C. Zooplankton abundance in a coastal station off the Ria de Aveiro inlet (north-western Portugal): relation with tidal and day-night cycles. Acta Oecol., v. 24, Suppl. 1, p. S175-181, 2003

MORGAN, C. A.; CORDELL, J. R.; SIMENSTAD, C. A. Sink or swim? Copepod population maintenance in the Columbia River estuarine turbidity-maxima region. Mar. Biol., v. 129, n. 2, p. 309-317, 1997.

PERILLO, G. M. E; PICCOLO, M. C. Tidal response in the Bahía Blanca estuary, Argentina. J. coast. Res., v. 7, n. 2, p. 437-449, 1991.
PICCOLO, M. C.; PERILlO, G. M. E. Physical characteristics of the Bahía Blanca estuary (Argentina). Estuar. coast. Shelf Sci., v. 31, p. 303-317, 1990.

RODDIE, R.; LEAKEY, R. J.; BERRY, A. Salinitytemperature tolerance and osmoregulation in Eurytemora affinis (Poppe) (Copepoda: Calanoida) in relation to its distribution in the zooplankton of the upper reaches of the Forth Estuary. J. expl mar. Biol. Ecol., v. 79, p. 191211, 1984.

VAN DE KREEKE, J.; DAY, C. M.; MULDER, H. P. J. Tidal variations in suspended sediment concentration in the Ems estuary: origin and resulting sediment flux. J. Sea Res., v. 38, p. 1-16, 1997.

VELEGRAKIS, A. F.; GAO, S.; LAFITE, R.; DUPONT, J. P.; HUAUlT, M. F.; NASH, L. A.; COLlinS, M. B. Resuspension and advection processes affecting suspended particulate matter concentrations in the central English Channel. J. Sea Res., v. 38, p. 17-34, 1997.

WEEKS, A. R.; SIMPSON, J. H.; BOWERS, D. The relationship between concentrations of suspended particulate matter and tidal processes in the Irish Sea. Continent. Shelf Res., v. 13, p. 1325-1334, 1993.

(Manuscript received 28 June 2010; revised 26 October 2010; accepted 05 March 2011) 